\title{
機能性磁性ナノ粒子を用いた三次元組織構築技術
}

\author{
井藤 彰, ${ }^{*, a}$ 本多裕之, $b$ 上平正 道 ${ }^{a}$
}

\section{Construction of 3D Tissue-Like Structure Using Functional Magnetite Nanoparticles}

\author{
Akira ITO, ${ }^{*, a}$ Hiroyuki HondA, ${ }^{b}$ and Masamichi KAMIHIRA ${ }^{a}$ \\ ${ }^{a}$ Department of Chemical Engineering, Faculty of Engineering, Kyushu University, 744 Motooka, Nishi-ku, \\ Fukuoka 819-0395, Japan, and ${ }^{b}$ Department of Biotechnology, School of Engineering, \\ Nagoya University, Furo-cho, Chikusa-ku, Nagoya 464-8603, Japan
}

(Received August 1, 2007)

\begin{abstract}
Magnetic nanoparticles for medical applications have been developed by many researchers. Since these nanoparticles have unique magnetic features not present in other materials, they can be applied to special medical techniques. Magnetite cationic liposomes (MCLs), one group of the cationic magnetic particles, can be used as carriers to introduce magnetite nanoparticles into target cells since their positively charged surface interacts with the negatively charged cell surface. Magnetite nanoparticles conjugated with antibodies (antibody-conjugated magnetoliposomes, AMLs) are applicable to introduce magnetite nanoparticles specifically into target cells, even when target cells coexist with other kinds of cells. Since the cells labeled with magnetite nanoparticles could be manipulated using magnets, we applied this technique to tissue engineering and termed it 'magnetic force-based tissue engineering (Mag-TE)'. Both magnetic force and functionalized magnetite nanoparticles were used in a process of tissue engineering: construction of multilayered cell sheet-like structures and tubular structures. Thus, the applications of these functionalized magnetite nanoparticles with their unique features will further improve tissue engineering techniques.
\end{abstract}

Key words — magnetic nanoparticle; 3-D cell culture; tissue engineering; liposome; magnetite

\section{1. はじめに}

Tissue engineering の定義は, 「生命科学と工学の 協力によって生体の機能を維持し，また失われた機 能を代替する臟器あるいは物質を創造するための学 際的研究分野」であり, ${ }^{1)}$ 医学と工学の融合分野と いった，筆者ら工学部の研究者にとっても，最も工 キサイティングな研究領域の 1 つである.

筆者らは生物化学工学に携わる研究者として,「細 胞を物理的にハンドリングする」といつた生物プロ セス工学的な視点から, より高度な臓器構築が要求 される次世代の Tissue engineering におけるキーテ クノロジーになると考えられる「細胞の配置・配列 技術」について，磁性ナノ粒子を用いた細胞の磁気 誘導の研究開発を行っており，磁性ナノ粒子（mag

a九州大学大学院工学研究院化学工学部門 (T819-0395 福岡市西区元岡 744), $b$ 名古屋大学大学院工学研究科 化学・生物工学専攻（干464-8603 名古屋市千種区不老 町)

*e-mail: akira@ chem-eng.kyushu-u.ac.jp

本総説は, 日本薬学会第 127 年会シンポジウム S45 で 発表したものを中心に記述したものである. netic nanoparticles）と磁力（magnetic force）を用 いた tissue engineering 技術として“Mag-TE”とい う技術を開発している，Mag-TEは，磁性ナノ粒子 であるマグネタイトを細胞内に取り込ませることに よって細胞を磁気標識し, 磁石を目的の位置に設置 して, 磁力で細胞を引き付けることによって, 細胞 を任意の場所に配置・接着させて, 細胞を高密度に 集積させる, ${ }^{2-5)}$ あるいは, 細胞からなる三次元組 織を構築する手法である. ${ }^{6-12)}$ その中でも, 三次元 組織の構築法は, 次世代の Tissue engineering にと って大変重要な技術であり, さらには医療のみなら ず，動物実験代替法等の薬学分野にも応用できる非 常に魅力的なテーマである。本稿では，今まで筆者 らが行った Mag-TE 法を用いた三次元組織構築法 の研究に焦点を当てて紹介する.

\section{2. 機能性磁性ナノ粒子}

磁性粒子は，磁束密度の高い方へ引き寄せられる 性質を持つため, DNA 分子から細胞まで幅広い生 体物質の磁気分離の分野において, 盛んに研究が行 われてきた。最近では，核磁気共鳴画像（Magnet- 
ic resonance imaging; MRI）の造影剤やがんの温熱 療法といった医療分野においても利用されてきてい る. ${ }^{13)}$ 磁性体であるマグネタイト $\left(\mathrm{Fe}_{3} \mathrm{O}_{4}\right)$ は, 鉱 物として自然界に存在しており，生体内にも微量に 存在していることが知られている，筆者らはマグネ タイトをナノメーターサイズの球形に成形したもの を用いて，標的の細胞へ特異的に集積させることが できる機能性磁性ナノ粒子としてのリポソーム封入 型磁性ナノ粒子の開発を行ってきた.

われわれのグループは, カチオニックリポソーム にマグネタイトのナノ粒子を包埋することで，正電 荷脂質包埋型マグネトリポソーム（magnetite cationic liposome; MCL, Fig. 1) を開発した. ${ }^{14)}$ MCL は正電荷を持っているために，一般的に表面に負電 荷を持っているほとんどの細胞に結合することがで き，さらにリポソームの効果として，マグネタイト をエンドサイトーシス等の作用で細胞内に導入する ことができる，一方，多種類の細胞が混在する場合 には目的の細胞だけを選択的に結合させることはで きない。そこで筆者らは，中性の電荷を持つリポ ソームでマグネタイトを包埋し，さらに表面に細胞 特異的な抗体を結合させることで，抗体結合型マグ ネトリポソーム (antibody-conjugated magnetolipo-

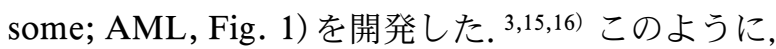
細胞にマグネタイトを取り込ませて磁気ラベルし, 細胞を磁気操作するための材料としての機能性磁性 ナノ粒子を開発した。筆者らは今までに，間葉系幹 細胞 (mesenchymal stem cell; MSC) の表面抗原で ある CD105 に対する抗体を結合させた AML を用 いて，ヒト骨髄液中から MSC を分離し，さらに， 磁力で MSC の培養面積を規定することで，細胞の
播種密度を高くし，オートクライン作用などの細胞 間相互作用を利用して，数少ない骨髄中の MSC を 増幅するための有効な培養方法を開発した。 ${ }^{3)}$ 一 方，先述したように，MCL はほとんどの細胞に結 合することができるため, 特異性を要する細胞の分 離には向かないが，汎用性を有するため，標的細胞 を分離・増幅したのちのプロセス（本稿で解説する 三次元構築技術）における細胞の磁気ラベルには, 威力を発揮する.

\section{3. 表皮細胞シートの構築}

培養細胞を in vitro で自然沈降によって積み上げ ていっても，その上下の細胞同士が即座に接着して 重層化することはない。それは，タンパク質分解酵 素を用いた細胞回収法では細胞が接着するための細 胞外マトリックス（Extracellular matrix; ECM）が 分解されてしまうことによる，筆者らは，磁性微粒 子で細胞を標識し，磁力で引き付けることにより， 細胞間を密に長時間維持することによる三次元培養 が可能となり, 細胞間接着を促進させて三次元重層 組織を構築することができるのではないかと考え た。そこで，表皮角化細胞を Mag-TE 法によって 重層化させることで，表皮細胞をシート状に成形し て培養表皮シートが構築できるかを検討した。 ${ }^{6}$

培養表皮は Tissue engineering の分野で最も開発 が進んでいる組織である．表皮角化細胞の初代培養 は，線維芽細胞が混入してしまい，培養を続けると 線維芽細胞の増殖が優勢になってしまう。1975 年 に Rheinwald とGreen は，放射線照射して不活性 化したマウス線維芽細胞をヒト表皮角化細胞の初代 培養に混ぜることで，ヒト線維芽細胞の増殖を抑え ることに成功し，さらにマウス線維芽細胞が死滅す

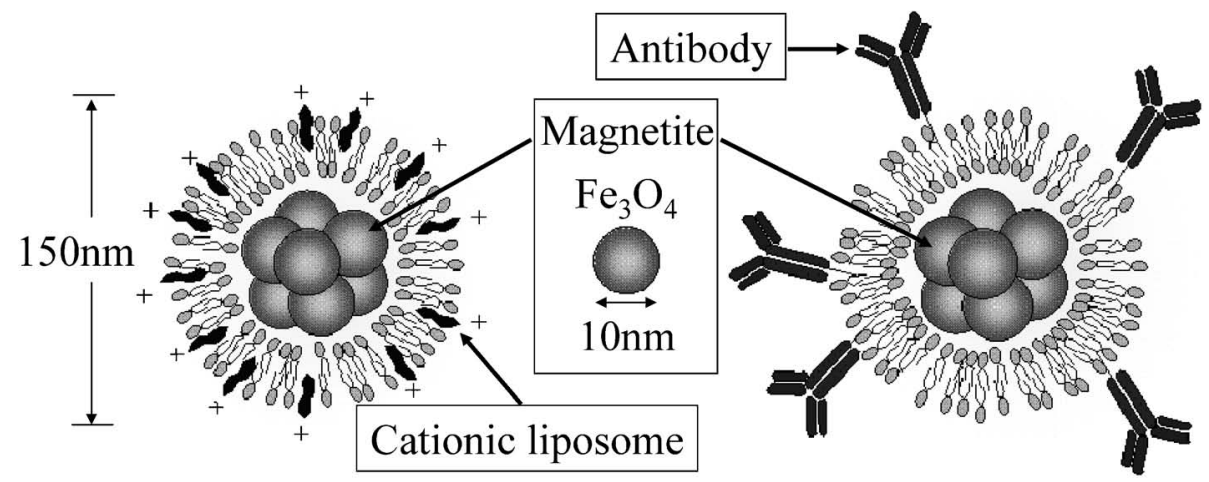

Fig. 1. Functional Magnetite Nanoparticles

Magnetite cationic liposomes (MCLs, left figure) and antibody-conjugated magnetoliposomes (AMLs, right figure) are illustrated. 
ると表皮角化細胞が重層化することから培養表皮

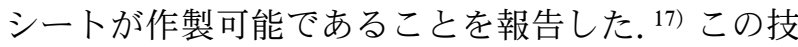
術は培養表皮シートの優れた作製方法として現在も 利用されているが，異種細胞であるマウスの細胞が ヒト表皮シートに混入する危険性が考えられる。ま た，この技術におけるもう 1 つの改良すべき点は， 作製したシートを酵素処理で培養表面から剥がす工 程にある．表皮角化細胞は足場依存性の細胞である ことから，作製したシートは培養表面に接着タンパ ク質を介して接着している。したがって，接着面か ら剥離させるためにはディスパーゼ等のプロテアー ゼを用いる必要があるが，この酵素処理によって培 養表皮シートの細胞間の結合が切断されて，シート の強度が弱くなってしまう。したがって，酵素処理 なしで培養細胞シートを回収できれば，シートの強 度を損なうことがなく，しかも酵素を添加してさら に洗浄除去するといつた工程を除くことができるた め，大変有用であると考えられる，そこで筆者らは，

Mag-TE 法によって，マウスの細胞を用いずに表皮 角化細胞を重層化させて培養表皮シートを作製し， さらに酵素を用いないでシートを剥離することがで きるかどうか検討した.

Mag-TE 法による培養表皮シート作製法の概念図
を Fig. 2 (A) に示した．MCL を添加することによ って磁気ラベルした細胞を，タンパク質や細胞がほ とんご吸着しない材質でできた超低接着性の培養血 に，コンフルエント時の細胞数の 5 倍の細胞数で播 種し，円柱磁石を培養血底面に設置して 1 日培養し たところ，均一な 5 層からなる細胞シートが形成さ れた（Fig. 2(B))。また，このシートの細胞間結合 を電子顕微鏡で観察したところ，接着斑であるデス モソームが観察された (Fig. 2(C))。このことから, Mag-TE で作製した細胞シートは，磁力で凝集して いるだけではなくて，細胞同士が接着タンパク質を 介して能動的に結合していると考えられる．作製し たシートは，超低接着性表面上で磁力によって物理 的に集積させて培養しているため，磁力を解除する ことで, 酵素処理なしで培養表皮シートが回収でき た。さらに，Mag-TE 法で作製した培養表皮シート は，シート形成後もマグネタイトを含んでいたこと から，作製したシートが棒磁石を用いることで回収 できるかを検討した，結果として，培養血の底面に 設置した磁石を外すことで表皮細胞シートを培養表 面から剥離させることができ，培養液の表面に棒磁 石を近づけたところ，棒磁石にシートを引き寄せて 回収することができた。培養組織は脆弱な場合が多

A
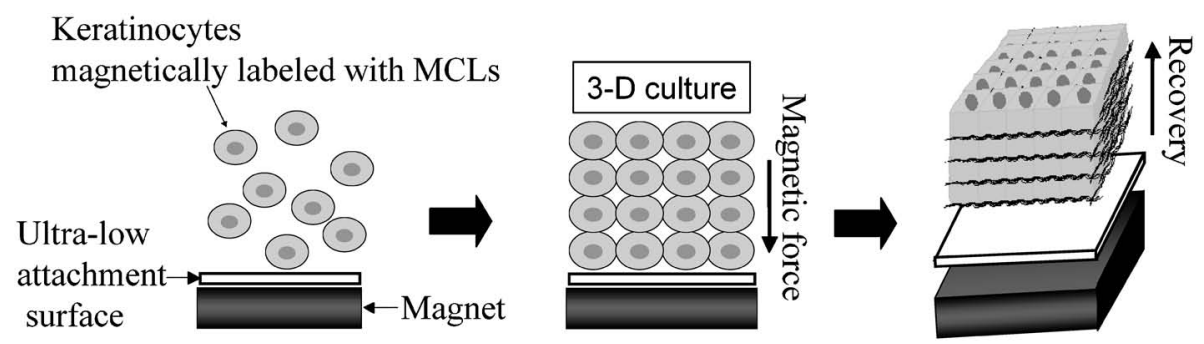

Accumulation of cells Recovery of cell sheets by magnetic force

B

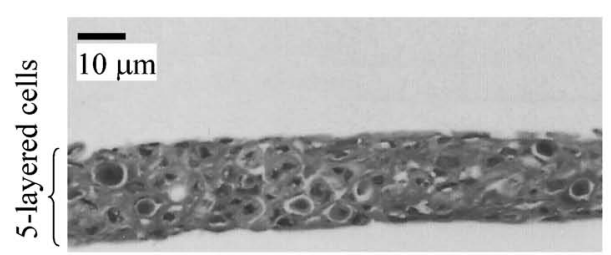

C

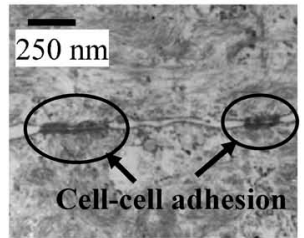

Fig. 2. Construction of Keratinocyte Sheets by Mag-TE

(A) Schematic of Mag-TE for keratinocyte sheets. After addition of the MCLs, keratinocytes were seeded into an ultra-low-attachment plate whose surface was comprised of a covalently bound hydrogel layer that is hydrophilic and neutrally charged. A cylindrical neodymium magnet was then placed at the reverse side of the low-attachment plate to provide magnetic force vertical to the plate, and the cells were cultured. At 1 day after the start of culture, the magnet placed at the reverse side of the ultra-low-attachment plate was removed. Then, the keratinocyte sheets constructed by Mag-TE were harvested. (B) Bright-field photographs of hematoxylin and eosin-stained cross-sections of keratinocyte sheets constructed by Mag-TE. Keratinocytes labeled with MCLs formed even 5-layered sheets. (C) Transmission electron microscope observation revealed desmosomes connecting adjacent cells in sheets fabricated by Mag-TE. 
いことから，このように磁力で培養組織を回収でき る点は Mag-TE 法の大きな利点であり，また，培 養組織の回収を自動化した培養装置及びシステムの 開発に結び付く可能性がある.

\section{4. 肝臓様組織の構築}

生体組織は複数種類の細胞が情報伝達しながら機 能していることから，複数種類の細胞を三次元的に 配置する技術の開発が望まれている，例えば肝臓 は，肝実質細胞と非実質細胞といつた複数種類の細 胞からなり立っており，それらを共培養することに よって肝機能が促進されるといつた報告がある. ${ }^{18)}$ そこで筆者らは，Mag-TE 法によって，肝蔵のよう な複数種類の細胞が三次元的に綿密に相互作用する ことによって機能が発揮される器官が, 重層組織と

して構築できるかについて調べた. ${ }^{7)}$

まず，細胞を磁気ラベルするために，MCL をヒ 卜大動脈血管内皮細胞 (human aortic endothelial cell; HAEC）の培養液に添加した。磁気ラベルした HAEC を, 単層培養したラット肝実質細胞上に添 加し，磁石を培養血底面に設置して培養したとこ ろ，培養血全体に渡って均一に HAEC が沈降し， 肝実質細胞に接着した（Fig. 3)。一方，磁石を用 いない場合には，HAEC は肝実質細胞上に接着し
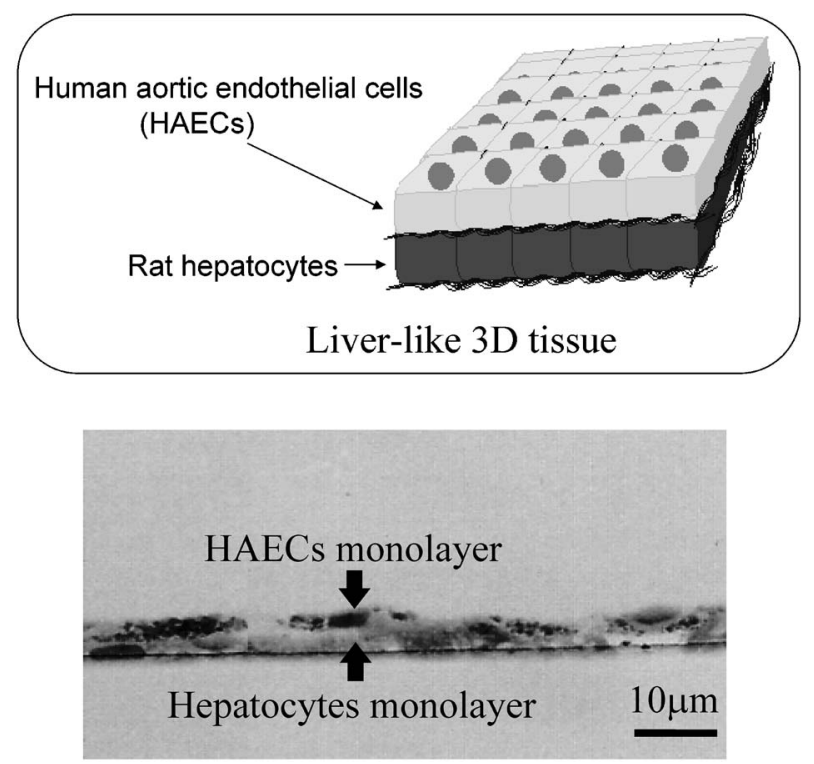

Fig. 3. Construction of 3-D HAEC and Hepatocyte Co-cultures by Mag-TE

HAECs were incubated in medium containing MCLs for $8 \mathrm{~h}$ and seeded onto rat hepatocyte monolayers, then a magnet was positioned. A brightfield photograph of hematoxylin and eosin-stained sections of co-cultured hepatocytes and HAECs with a magnet is shown. In the presence of a magnet, HAECs evenly attached to the hepatocyte layer throughout the wells.
なかった。次に, 肝実質細胞の細胞層上に HAEC を磁力で重層化した 2 種類の細胞からなる三次元共 培養において, 肝実質細胞の機能が充進するか検討 した．肝機能の評価としてアルブミン生産を測定し たところ，Mag-TE 法で共培養を行うことでアルブ ミン生産能は有意に増加することが分かった．以上 の結果から，Mag-TE 法を用いることで，通常三次 元的には接着しない細胞同士（肝実質細胞と HAECs）を磁力によって接着させることができ， この三次元共培養によって, 肝実質細胞の機能を六 進させることができた.

\section{5. 心筋細胞シートの構築}

心臟病は日本人の 3 大死因の 1 つであり, 年間 15 万人以上が亡くなっている。筆者らは，Mag-TE により心筋組織を再構築した「機能する」心筋細胞 シートの創製を目指した。

MCL で心筋細胞を磁化し, 心筋細胞シートを作 製した (Fig. 4(A)). ${ }^{10)}$ 作製した心筋細胞シートは, 8 層の均一な細胞シートであることが, 細胞シート の断面の顕微鏡写真により確認された.

心臓は一定のリズムで拍動しているが，これは連 結した心筋細胞の間にギャップ結合が存在するため に, 活動電位が細胞から細胞へと急速に広がるから である，そこで，作製した心筋細胞シートの内部に ギャップ結合が存在するかどうか調べるために，免 疫組織染色を行ったところ，心筋細胞シート内部に ギャップ結合タンパク質であるコネキシン 43 が存 在することが分かった。 さらに，活動電位が心筋細 胞シート内を伝わつていることを，微小電極アレイ 上で心筋細胞シートを作製して調べた. Figure 4 (B)には, 64 個の微小電極の中から，隣り合った位 置にある 6 つの電極（電極番号 $10,18,26,34,42$, 50）から得られた波形を示す。電極番号が若い順に 波形が左から右にシフトしていく様子が確認され た。これらのことから心筋細胞シート内にはギャッ プ結合が存在し，実際に活動電位も伝わっているこ とが分かった。これらの結果から，Mag-TE で作製 した心筋細胞シートは，電気的な結合を持った「機 能する」組織になり得ると考えられる.

\section{6. 間葉系幹細胞（MSC）シートの構築}

MSC は骨髄中に存在する体性幹細胞で, 骨芽細 胞，骨細胞，軟骨細胞などに分化することが知られ ており，比較的容易に採取できるため, Tissue en- 

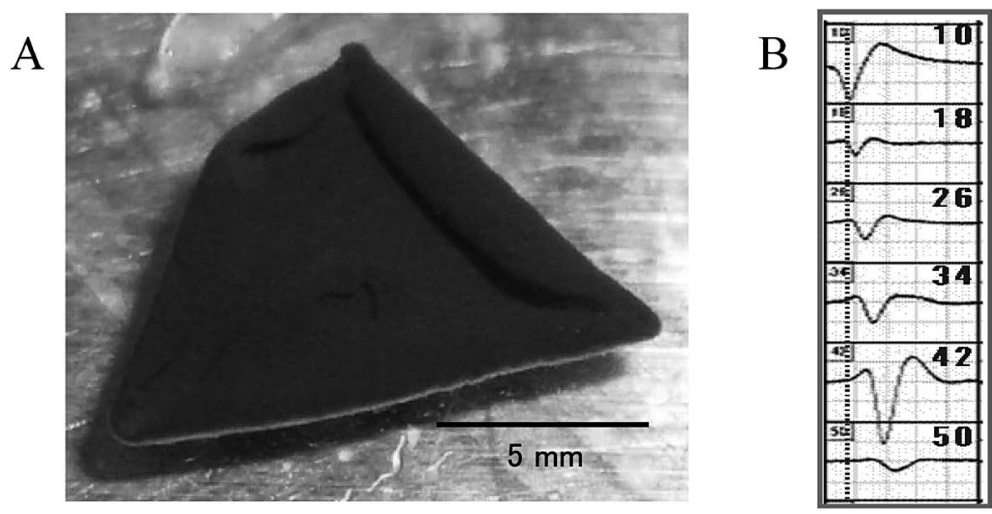

Fig. 4. Construction of Cardiomyocyte Sheet by Mag-TE

(A) Bright-field photograph of cardiomyocyte sheet constructed by Mag-TE. (B) Representative of signals (from microelectrode nos. 10, 18, 26, 34, 42, 50) by cardiomyocytes within the sheet constructed by Mag-TE, acquired by the multielectrode extracellular potential mapping with 8 by 8 microelectrodes.

\section{A}

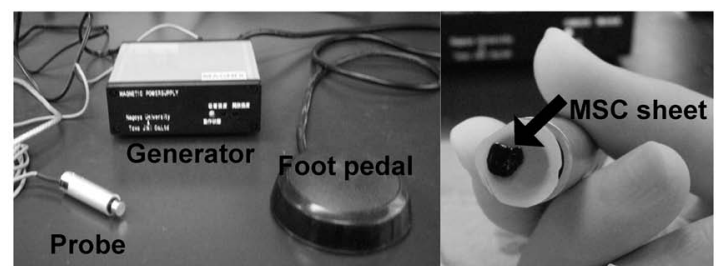

B

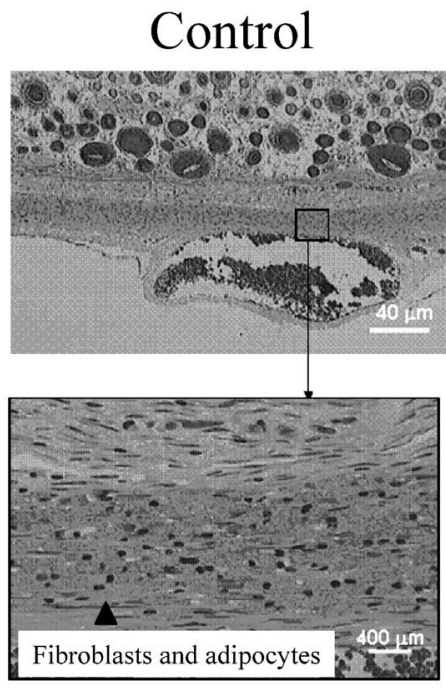

\section{Transplantation}

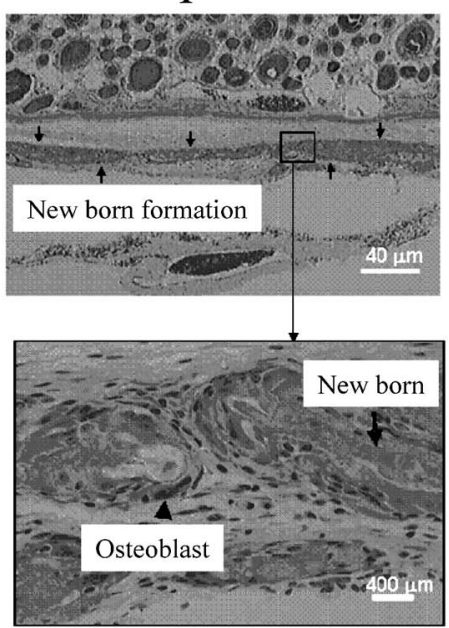

Fig. 5. Transplantation of Mesenchymal Stem Cell Sheets Constructed by Mag-TE

(A) An electromagnet for transplantation of MSC sheets. (B) Histological analysis (hematoxylin and eosin staining) of in vivo bone formation by MSC sheets on day 14 after transplantation. Low- and high-power histology of defects without implanted MSC sheets (control) and with implanted MSC sheets are shown. Numerous fibroblasts and adipocytes were observed in the control. When MSC sheets were transplanted, new bone formation and osteoblasts were apparently observed throughout the defect site.

gineering において非常に有効な細胞源として注目 を集めている．筆者らは，Mag-TE により MSCの シートを作製し，さらに分化させることで骨組織の 再生を試みた. ${ }^{11)}$

作製した MSC シートは，細胞培養皿上で適切な 条件下で培養すると，骨芽細胞シートに分化した。 さらに，MSC シートをラット頭蓋骨に作製した骨
欠損部に移植して，骨組織が再生されるか調べた.

Figure 5 (A) に示すように，Mag-TE で作製した MSC シートを，独自に開発した電磁石で回収・運 搬して，患部に移植した。移植 14 日後に，移植し た部分で骨組織が再生しているかを調べたところ, コントロールのシート移植なしのラットでは，骨芽 細胞，骨細胞がみられなかったのに対し，シートを 
移植したラットでは，シートを移植した部分に骨芽 細胞と新生骨が観察された（Fig. 5(B))。これらの 結果から, Mag-TEで作製された MSC シートは, 骨の Tissue engineering に有用である可能性が示さ れた。

\section{7. 毛細血管網を含む細胞シートの構築}

これまで述べたように, 様々な種類の三次元組織 の構築を行ってきた。しかし，それらは分厚い組織 ではなく細胞シートであり，厚さが数百 $\mu \mathrm{m}$ を超え る分厚い組織を構築するためには, 酸素や栄養を組 織内部に供給する血管を，作製した組織内に含ませ る必要がある、そこで，筆者らは，Mag-TEにより 皮膚線維芽細胞シートを作製し, この細胞シート内 に血管内皮細胞を混ぜて培養し，毛細血管を形成さ せることを目指した. ${ }^{12)}$

毛細血管が形成されるためには，血管内皮細胞の 周りの環境が重要である。しかし, 一般的な細胞回 収法では酵素処理を行うため, 細胞外マトリックス などの重要な成分を分解してしまう。一方，前述し た通り，Mag-TEでは，作製した細胞シートが酵素 処理を行わずに回収できるため, 正常ヒト皮膚線維
芽細胞シート内にはフィブロネクチンや I 型コラー ゲンといった毛細血管を形成させるのに重要な ECM が多く含まれていることが観察された。 そこ で, 皮膚線維芽細胞シートに血管内皮細胞を混ぜて 培養したところ，血管内皮細胞に管状構造を形成さ せ (Fig. 6(A)), さらに網目状のネットワークを形 成させることに成功した（Fig. 6(B)）。

\section{8. 管状組織の構築}

Mag-TE を用いることで, 様々な三次元組織が構 築可能であることを示した，上述したような，表皮 のような単一細胞を重層化させることで機能が促進 される組織や, 肝臓といつた複数の種類の細胞が綿 密に相互作用することによって機能が発揮される組 織が，三次元重層組織として構築できた。 さらに, 本手法の最大の利点として, 磁力を用いることで, 重力方向以外の標的部位にも目的細胞を特異的に配 置・配列できることがある.このことにより, 細胞 を自然沈降させても構築が不可能な形状の組織を構 築することができる.

従来の Tissue engineering 技術で，血管や尿管の ような管組織を形成させるには，管状のポリマーに
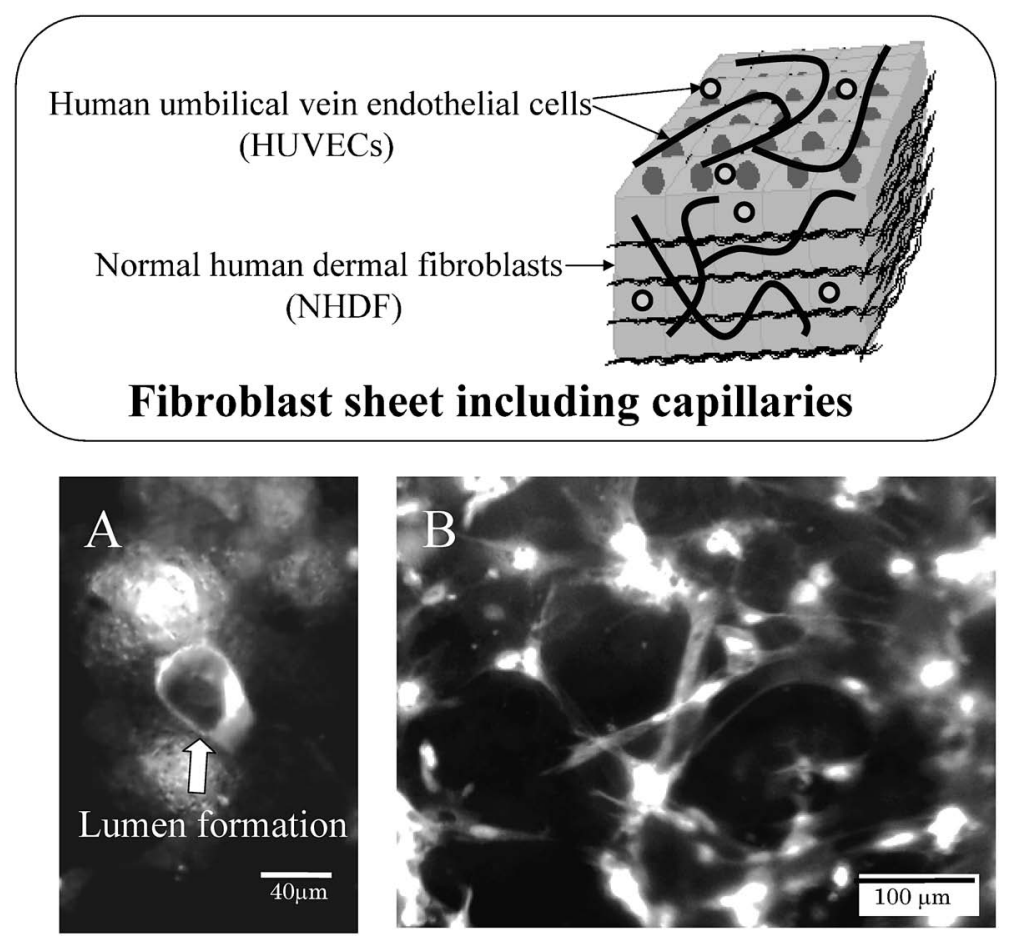

Fig. 6. Incorporation of Capillary-like Structures into Dermal Cell Sheets Constructed by Mag-TE

Two major morphologic changes that regulate HUVEC tube development include lumen formation and sprouting, which control how HUVECs interconnect into 3-D networks. Fluorescence microscopic images of HUVECs co-cultured with NHDF sheets revealed lumens consisting of two HUVECs (A), as well as sprouting with long cord-like structures (B). 
細胞を自然沈降させて接着させる方法しかなかつ た。この場合，細胞を均一にポリマーに接着させる ことが困難であり，また，多くの細胞はポリマーに 接着しないで流れていってしまうといった問題点が あった。そこで，筆者らは，管の軸を磁石にするこ とによって，機能性磁性微粒子でラベルした細胞を ロスすることなく，確実に標的した位置に細胞を配 列でき，軸の磁石を引き抜くことで管構造が完成す るのではないかと考え，Mag-TE を管状組織の構築 に応用した. ${ }^{9)}$ Figure 7 (A) に Mag-TE による管状組 織構築法の概念図を示す，MCL で磁気ラベルした イヌの移行上皮細胞（urothelial cell; UC）の上か ら，棒磁石を挿入したシリコンチューブを転がした ところ，シリコンチューブ表面に細胞が吸着した。 この細胞をコラーゲンで覆い，芯になっているシリ コンチューブを引き抜くことによって，管状構造を 構築することができた．Mag-TE 法で作製した管状 構造は, UC からなる 5 層の多細胞層構造を取って おり，生体組織と類似した尿管構造を構築すること
ができた（Fig. 7 (B))。血管は，血管内皮細胞 （endothelial cells; EC）からなる内膜，血管平滑筋 細胞 (smooth muscle cells; SMC) からなる中膜, 線維芽細胞（Fibroblast； FB）からなる外膜，とい つた 3 種類の細胞層が多層構造で構成されている. 筆者らは，MCL をヒト $\mathrm{EC} ，$ ヒト $\mathrm{SMC}$ ，マウス FB のそれぞれの細胞に取り込ませて，それらを順番に 棒磁石を挿入したシリコンチューブに巻き付けてい くことによって，3 種類の細胞層構造からなる血管 組織を構築することに成功した（Fig. 7(C)).

\section{9. 結語}

生体組織や臓器は三次元細胞組織であることか ら, 細胞は, 細胞シートのような三次元構造を取ら せることで，より本来の性質に近づくと考えられ る。つまり，細胞シートの構築は，細胞に本来の機 能を発揮させ, 生体組織・臟器を再生・再構築する 上で非常に重要な技術である．筆者らは現在，従来 の Tissue engineering 技術では構築不可能な複雑な 構造と機能を持つ器官構造を再構築することを目標

A

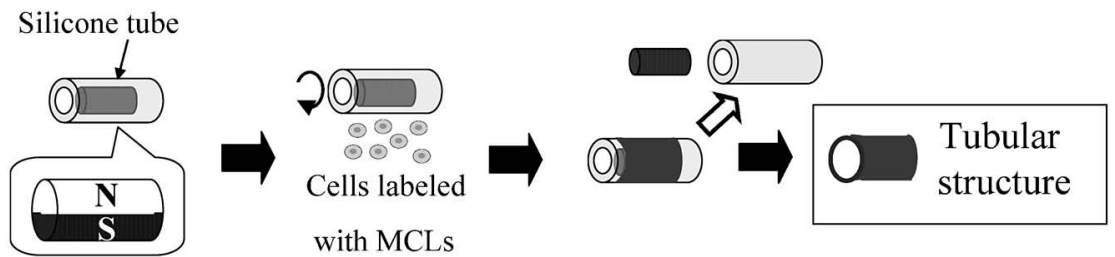

B

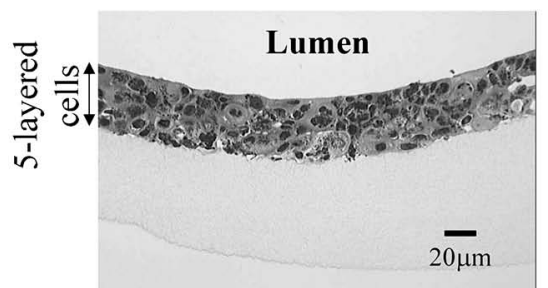

C

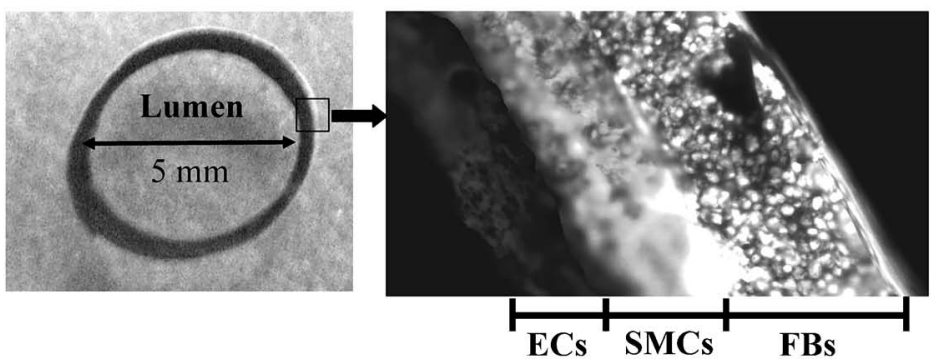

Fig. 7. Construction of Tubular Tissues by Mag-TE

(A) Procedure for construction of tubular structures by Mag-TE. A cylindrical magnet whose magnetic poles were on its curved surface was inserted into a silicon tube. Then, this magnet/tube combination was rolled over the magnetically labeled cells. The canine urothelial cells were used for construction of a tissue-engineered ureter. For the construction of blood vessels, the endothelial cells (ECs) were applied first, followed by application of the smooth muscle cells (SMCs) and fibroblasts (FBs). After 1-d culture period, the silicon tube and cylindrical magnet were pulled out of the cell construct, producing tubular constructs of tissue engineered urothelial and vascular tissue. (B) Bright-field micrograph of hematoxylin/eosin-stained cross-sections of urothelial tissue constructed Mag-TE. (C) Fluorescence microscopy of the vascular tissue constructed by Mag-TE. 
に, Mag-TE 法をいろいろな臓器再生に展開しつつ ある。

\section{REFERENCES}

1) Langer R., Vacanti J. P., Science, 260, 920926 (1993).

2) Ito A., Hibino E., Honda H., Hata K., Kagami H., Ueda M., Kobayashi T., Biochem. Eng. J., 20, 119-125 (2004) .

3) Ito A., Hibino E., Shimizu K., Kobayashi T., Yamada Y., Hibi H., Ueda M., Honda H., $J$. Biomed. Mater. Res. B Appl. Biomater., 75, 320-327 (2005).

4) Ino K., Ito A., Honda H., Biotechnol. Bioeng., 97, 1309-1317 (2007) .

5) Ito A., Ino K., Kobayashi T., Honda H., Biomaterials, 26, 6185-6193 (2005).

6) Ito A., Hayashida M., Honda H., Hata K., Kagami H., Ueda M., Kobayashi T., Tissue Eng., 10, 873-880 (2004).

7) Ito A., Takizawa Y., Honda H., Hata K., Kagami H., Ueda M., Kobayashi T., Tissue Eng., 10, 833-840 (2004) .

8) Ito A., Hibino E., Honda H., Kobayashi C., Terasaki H., Kagami H., Ueda M., Kobayashi T., Tissue Eng., 11, 489-496 (2005).

9) Ito A., Ino K., Hayashida M., Kobayashi T.,
Matsunuma H., Kagami H., Ueda M., Honda H., Tissue Eng., 11, 1553-1561 (2005) .

10) Shimizu K., Ito A., Lee J. K., Yoshida T., Miwa K., Ishiguro H., Numaguchi Y., Murohara T., Kodama I., Honda H., Biotechnol. Bioeng., 96, 803-809 (2007).

11) Shimizu K., Ito A., Yoshida T., Yamada Y., Ueda M., Honda H., J. Biomed. Mater. Res. B Appl. Biomater., 82, 471-480 (2007).

12) Ino K., Ito A., Kumazawa H., Kagami H., Ueda M., Honda H., J. Chem. Eng. Jpn., 40, 51-58 (2007).

13) Ito A., Shinkai M., Honda H., Kobayashi T., J. Biosci. Bioeng., 100, 1-11 (2005) .

14) Shinkai M., Yanase M., Honda H., Wakabayashi T., Yoshida J., Kobayashi T., Jpn. J. Cancer Res., 87, 1179-1183 (1996) .

15) Shinkai M., Le B., Honda H., Yoshikawa K., Shimizu K., Saga S., Wakabayashi T., Yoshida J., Kobayashi T., Jpn. J. Cancer Res., 92, 1138-1145 (2001).

16) Ito A., Kuga Y., Honda H., Kikkawa H., Horiuchi A., Watanabe Y., Kobayashi T., Cancer Lett., 212, 167-175 (2004).

17) Rheinwald J. G., Green H., Cell, 6, 331-343 (1975) .

18) Bhatia S. N., Balis U. J., Yarmush M. L., Toner M., FASEB J., 13, 1883-1900 (1999) . 